\title{
Effects of Computer-Assisted Jigsaw II Cooperative Learning Strategy on Physics Achievement and Retention
}

\author{
Isiaka Amosa Gambari \\ Federal University of Technology, Nigeria \\ Mudasiru Olalere Yusuf \\ University of llorin, Nigeria
}

\begin{abstract}
This study investigated the effects of computer-assisted jigsaw II cooperative strategy on physics achievement and retention. The study also determined how moderating variables of achievement levels as it affects students' performance in physics when Jigsaw II cooperative learning is used as an instructional strategy. Purposive sampling technique was used to select two senior secondary school class II (SSSII) physics students from two intact classes in Minna, Niger State, Nigeria. Eighty students from two intact classes were assigned into Jigsaw II and Individualized Computer Instruction (ICI) groups. ComputerAssisted Learning Package (CALP) on physics and Physics Achievement Test (PAT) were used as treatment and test instruments. Analysis of Covariance and Scheffe's test were used for data analysis. Findings indicated that students taught physics using computerassisted Jigsaw II performed better and retained the physics concepts longer than those taught using individualized computer instruction. In addition, achievement levels had significant influence on their performance. Based on the findings, it was recommended among other that physics teachers should be encouraged use computer-assisted Jigsaw II cooperative strategy to enhanced students' performance.
\end{abstract}

Keywords: Jigsaw II; Computer-assisted instruction; Cooperative Learning; Achievement Levels; Retention; Physics

\section{Introduction}

Trends of development in the industrialized world show that Science, Technology, and Mathematics (STM) have been employed by many countries for rapid economic and technological transformation from agrarian to industrialized status (Essien, 2000). The technological development of any nation lies in the study of science. Science and technology would be incomplete without physics (Michael, 2006).

The significance of physics in all fields of science and technology has therefore made it imperative to be included in the curriculum of senior secondary school to be offered by science oriented students. To build a strong technological foundation, therefore, physics education needs to be given more attention and priority in Nigerian educational system. Unfortunately, in spite of the importance of physics as a requirement for many specialized science and engineering courses at the universities, students' performance at the secondary school level in the subject is not encouraging. 
The performance of students naturally in physics as a subject in the Senior Secondary School Certificate Examinations (SSSCE) from 2004 to 2011 is as shown in Figure 1 and in Niger State as reflected in Figure 2.

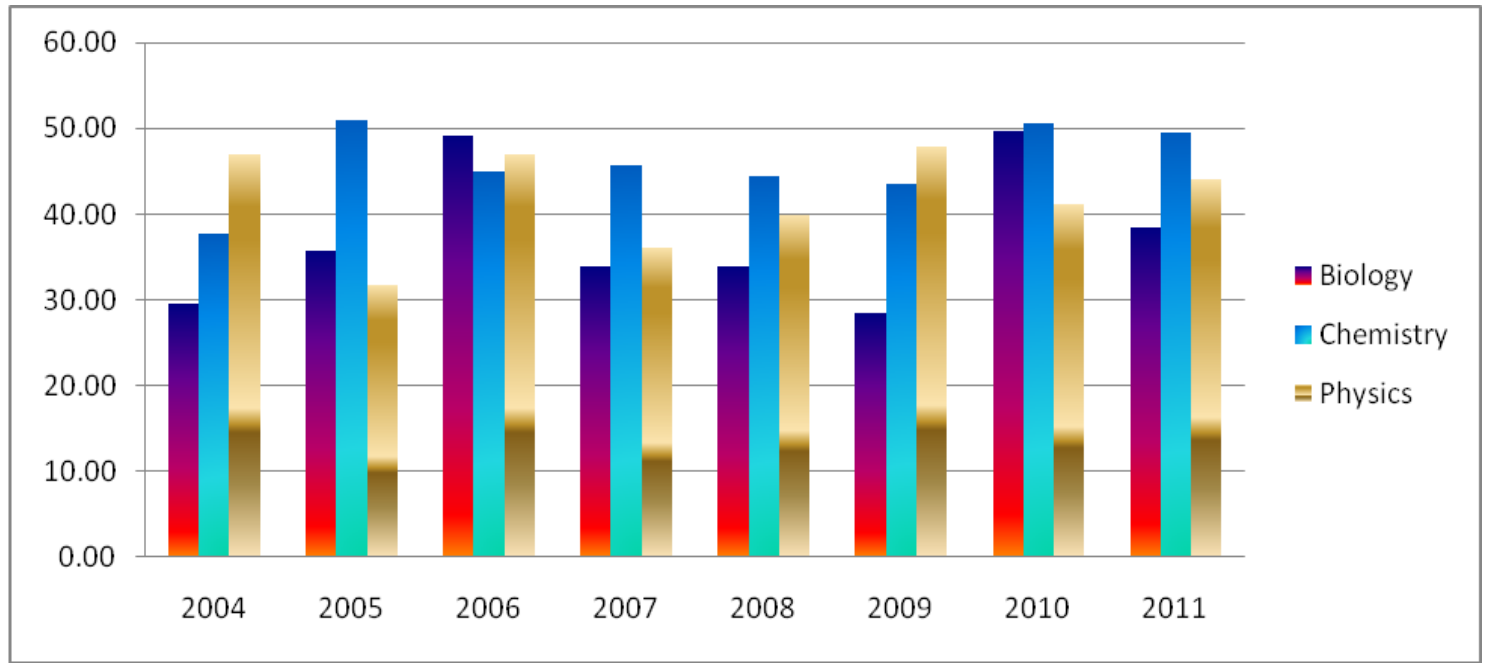

Figure 1. Performance in Biology, Chemistry and \& Physics from 2004 - 2011 in Nigeria

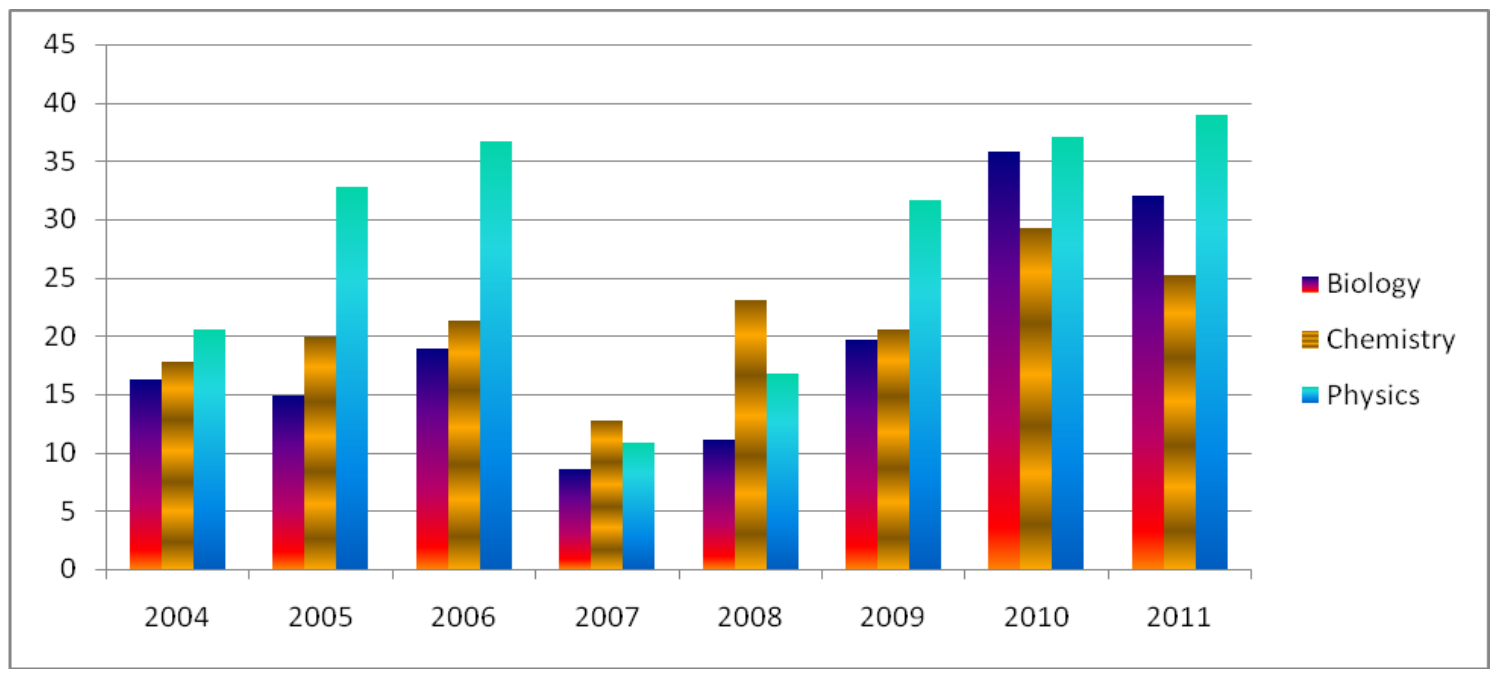

Figure 2. Performance in Biology, Chemistry and \& Physics from 2004 - 2008 in Niger State

Figure 1 reveal that the percentage of students that passed physics at credit level (A1-C6) was consistently less than $50 \%$ for the past 5 years (2004-2011) in Nigeria. In spite of the importance of physics to man and the society and government efforts to improve science instruction in schools, students' performance is still poor and below average. This has become a great concern to physics educators in Nigeria. In Niger State for example, the performance of physics students is worse than the national performances as revealed in Figure 2.

Figure 2 revealed the fluctuation in May/June WAEC (SSCE) results in physics in Niger State. Students' performance has been fluctuating between $20.53 \%$ to $36.67 \%$ and to $16.77 \%$ in the year 2004, 2006 and 2008 respectively for students with credit pass. Also, the number of students who registered for physics at both the national and state levels was the lowest compared with those who registered for biology and chemistry from 2004-2008. 
This poor performance in physics is very disturbing and if not checked, may jeopardize the placement chances of students in tertiary institutions, not only in physics education but also in other physics related disciplines. This has serious implications for national development, security, economy and manpower for a nation with a vision of becoming one of the twenty leading nations in science and technology by the year 2020 (Yar'adua, 2008).

Educational technology can be defined as a complex, integrated process involving people, procedures, ideas, devices, and organization, for analyzing problems and, devising, implementing, evaluating, and managing solutions to those problems, involved in all aspects of human learning. Educational technology can provide solutions to various classroom problems.

Poor instructional strategies, abstract nature of science concepts, lack of qualified teachers, poor infrastructure and inadequate laboratory facilities, teacher-centred instruction, and nonavailability and utilization of instructional materials among others were identified as the causes of students' poor performance in science subjects (Adegoke, 2011; Bajah, 2000; Gambari \& Gana, 2005; Okebukola, 1999; Mathew, 2002).

These findings have led a number of science educators to conclude that science subjects are not effectively taught in our schools (Adetona \& Rafiu, 2006; Okebukola, 2005; Olorukooba, 2007; Omosewo, 2000). Meanwhile, cooperative learning has been indicated by research to be effective and efficient in promoting and maximizing science learning outcome. This strategy is rare in Nigerian science classroom.

In this study, computer was used as a medium of instructional delivery. The field of educational technology focuses more on physical media that are designed and developed to improve the quality of teaching-learning process.

Research conducted regarding cooperative learning indicates that: Working together in a problem solving group means that an effort must be made in order to help all group members understand the task (Johnson, Johnson, \& Johnson-Holubec, 1993); students need to encourage one another's learning and feel responsible for helping each other for the sake of the group product (Cohen, 1994); a complex task ensures that students use task skills and teamwork skills in order to work together to solve the problem (Dishon \& O'Leary, 1984); effective group work requires metacognitive thought (Johnson, Johnson, \& Stanne, 1996); and, to ensure that small group processing takes place, time needs to be allocated for members to participate in group processing and structure needs to be provided in order for group members to process how they worked together (Johnson, Johnson, \& Johnson-Holubec, 1993). Therefore, to enhance the understanding of physics concepts, students must be more active in the classroom and must creatively acquire knowledge, especially in understanding and solving physics problems. Students should be given the opportunities to develop, interact, and share with friends through cooperative learning activity, so that the cognitive and affective development of students in science can be improved (Zakaria, Solfitri, Daud \& Abidin, 2013).

Empirical evidences on the use of cooperative learning in science revealed that Jigsaw II enhanced better performance among students in physics (Gambari, 2010; Keramati, 2010; Hanze \& Berger, 2007; Berger \& Hanze, 2009), in biology (Altiparmak \& Nakiboglu-Tezer, 2009; Moreno, 2009), and in chemistry (Mattinly, VanSickle \& Ronald, 2009). It was also reported that Jigsaw II is considerably more effective than individualistic instructional strategy and conventional classroom instruction respectively. A study conducted in Saudi Arabia by 
Alshammari (2015) revealed that students who were taught by the jigsaw strategy had a better understanding of the content as compared to the students who were taught by lecture. Similarly, Azmin (2016) reported that students enjoyed using the Jigsaw method and performed significantly better after the intervention. Contrarily, a study conducted by Şengül and Katranci (2014) on the effects of jigsaw technique on mathematics self-efficacy perceptions of seventh grade primary school students revealed that the jigsaw technique has no effects on students' mathematics self-efficacy perceptions. In addition, Martin and Roland (2007), Shaaban (2006) and Seaborn and Wilson (2002) found no significant difference in the achievement of students taught using Jigsaw II and those taught using conventional classroom, discussion methods and individualized instruction respectively. The findings on the use of Jigsaw cooperative learning are inconclusive; therefore, this study examined the effects of computer-assisted Jigsaw II Jigsaw II on students' performance in physics.

The issue of whether learners' achievement levels have influence on their academic performance has attracted the attention of researchers. Fuligni, Eccles and Barber (1995) showed that high and medium achievers were favoured than low achievers. However, Yusuf (2004) revealed that achievement levels had no influence on academic performance of the learners. Other studies have found that high, medium and low achievers were favoured in cooperative learning settings (Gambari, 2010; Yager, Johnson, Johnson, 1985). Again the study by Crosby and Owens (1993) found that different cooperative learning strategies can be employed to help low ability students to improve achievement, who had difficulties making success in the traditional classroom.

Slavin (1995) identified that cooperative learning has been linked to increased in the academic achievement of learners at all ability levels. Similarly, Ajaja and Eravwoke (2010) revealed that a significant higher achievement test scores of all students of varying abilities (high, medium \& low) in cooperative learning group than those in traditional classroom. They found non significant interaction effect between gender and ability, gender and method of instruction, ability and method of instruction, gender and ability on achievement.

Retention which is the ability to reproduce the learnt concept when the need arises has been a quite fundamental to some researchers. However, students' interests and retention could be aroused and retained through the use of an appropriate instructional media (Osemwinyen, 2009). In a study conducted by Tran and Vietnam (2014) on the effects of cooperative learning on the academic achievement and knowledge retention. The results showed that after approximately 8 weeks students who were instructed using cooperative learning achieved significantly higher scores on the achievement and knowledge retention posttests than did students who were instructed using lecture-based teaching. The study supports the effectiveness of cooperative learning in Vietnamese higher education. Kara (2008) reported significant difference between the experimental and control group in favour of the experimental group in posttest and retention test. However, Moreno (2009) conducted a study on botany students using an agent-based instructional program with three different learning approaches (traditional method, individual, jigsaw cooperative learning) and found no difference among learning approaches on retention.

The instructional values of cooperative learning strategies have been established in developed world. However, there are very little research efforts in developing nations like Nigeria that emphasized cooperative interaction in physics at the senior secondary school level. In addition, studies on the use of computer-assisted Jigsaw II cooperative learning is an innovation in Nigerian education system. Based on these, the present study examined the effects of 
computer-assisted Jigsaw II cooperative learning strategy on secondary school students' performance in physics.

\section{Research Hypotheses}

The following null hypotheses were tested in the study.

1. There is no significant difference in the performance of secondary school students taught physics using computer-assisted Jigsaw II cooperative settings and those taught using Individualized Computer Instruction (ICI).

2. There is no significant difference in the performance of high, medium and low achievement level students taught physics using computer-assisted Jigsaw II cooperative setting.

3. There is no significant difference in the retention of secondary school students taught physics using computer-assisted Jigsaw II cooperative settings and those taught using Individualized Computer Instruction (ICI).

\section{Methodology}

\section{Research Design}

The design is a quasi-experimental study of a non-randomized, non-equivalent, pretest, posttest, and control group design. The participants were 80 second year physics students from four intact classes from four different senior secondary schools in Minna, Niger State, Nigeria. The schools were purposively sampled based on six criteria: (i) equivalence (laboratories, facilities and manpower), (ii) school ownership (public schools), (iii) gender composition (mixed schools), (iv) ICT facilities (computer laboratories under the SchoolNet programme), and ( $v$ ) candidates' enrolment (Senior Secondary School Certificate in Education in physics for a minimum of ten years). The schools were randomly assigned to experimental group (computer-assisted Jigsaw II) and control (Individualized Computer Instruction, ICI) groups using simple random sampling technique. The experimental group $(n=42)$ was taught through computer-assisted Jigsaw II cooperative learning strategy, and control group $(n=38)$ was taught using $\mathrm{ICl}$ for six weeks. The data was collected through the Physics Achievement Test while Computer Assisted Learning Package (CALP) was used as a treatment instrument.

\section{Instrumentation}

(i) Physics Achievement Test (PAT) consists of 100 multiple-choice questions, adopted from past examination of West African Examination Council (WAEC, May/June, 1988-2008) and National Examination Council (NECO, June/July, 2000-2007). The questions in the test were based on the contents of the Computer Assisted Learning Package (CALP). Each of the stems of the PAT had five options (A - E) as possible answers to the questions and each question carry one point. The instrument (PAT) was administered to the experimental and control groups as pre-test and post-test. The test was validated by experts before it was administered on 40 randomly selected SSII students who were not involved in the study. Reliability coefficient of 0.90 was obtained using Kuder Richardson (KR-21). 
(ii) Computer Assisted Learning Package (CALP) was the treatment instrument, used at two different instructional settings (cooperative and individualised). The CALP was developed by the researchers and a programmer using "Macromedia Dreamweaver 8" as the overall platform. Other computer programmes and applications that were also utilized during the development process were Microsoft Word, Macromedia Fireworks 8, and Macromedia Flash 8. Macromedia Fireworks was used for specific texts, graphics and buttons, while Macromedia Flash was used for simulation. The package was face and content validated by computer programmers and educational technology experts; subject content (physics) specialists; and finally validated by 40 sampled students from a school within the population but did not partake in the study. The package contained two topics which were subdivided into sixteen lessons. The main menu of the package consisted of introduction, students' registration, list of lessons as in lesson 1, 2, 3, 4, .. 16 and exit. It adopted the drill and practice modes of Computer Assisted Instruction (CAI).

\section{Experimental Procedures}

In collecting the data for this research, the objectives and the modalities of the study were specified and operational guide was produced before the commencement of the treatment. Physics teachers in the experimental group were trained in the use of computer-assisted learning package and cooperative learning strategies while the teacher in the control group was trained on how to coordinate individualised computer instruction using the CALP package. The treatment period for all groups covered six weeks (two hours forty minutes per week). The students in the experimental group were heterogeneously divided into groups with three members each.

At the beginning of the study, PAT was administered on students in the sampled schools as pre-test. The CALP package was installed on standalone computer systems in all the selected schools. The physics contents were presented through the computer and the learners interacted and responded to the computer prompts. The computer presents information and display animation to the learner on each of the unit after which the students attempted some multiple-choice questions. The students could only proceed in a lesson on the condition that the questions were satisfactorily answered. The students must have had at least $100 \%$ mastery of one topic before moving on to the next. If after three attempts they do not get the answer correctly, the package immediately logs them out and the instructor had to be called before they could continue through another log-in. During the study, the experimental groups were exposed to the use of computer-assisted cooperative learning strategy (Jigsaw II) as treatment, while students in control group were individually exposed to the computer-assisted instructional package. Immediately after the treatment, PAT was administered as post-test and after four weeks.

\section{Procedures for Each Strategy}

The Computer-assisted Jigsaw II Cooperative Learning Strategy: In this strategy, students were divided into small heterogeneous groups called home groups, with three members in each group. Each member was assigned different responsibilities. Initially all students were assigned to study and understand the basic concepts of the materials. After this process, the researcher divided the content (the tasks) of the lesson into three and assigned it to each 
member in the home group. The students met in their home groups and studied the assigned tasks using Computer-Assisted Learning Package. Each member in the home group attempted learning the assigned task as an expert by referring to the computer package and the available resources. After completing the learning task in the home group, each member moved into expert group (Jigsaw II group) consisting of members from the other home groups who had been assigned the same portion of the material (task). In the Jigsaw II group (expert group), the participants discussed and shared their particular materials with other members of the group and discussed how to teach it to their members in the home group. The teammates returned to their home groups where they taught what they learned from the Jigsaw group to other members of their groups. In case of any difficulty and misconception, the expert group made second round meeting to discuss and clarify their doubts if any; and returned to their home groups, to re-teach the members and reach a consensus. Group processing form was completed after each lesson to determine the group behaviour and correct any irregularity within the teammates. High scoring teams were recognised and rewarded in the class.

Individualized Computer Instruction Method: It was used for the control group. In this method, students were taught the physics concepts using CALP package only. The computer presented the instruction on human-to-computer basis. Students proceeded with the physics contents and studied at their own rate without any assistance from their colleagues. Students answered the PAT test at pre-test and post-test individually.

\section{Data Analysis}

The PAT was administered as pretest and posttest. The data collected during the study were analysed using Analysis of Covariance (ANCOVA) and Scheffe's test using Statistical Package for Social Sciences (SPSS) version 13 at 0.05 alpha level.

\section{Results}

The results are presented based on the research hypotheses:

Hypothesis One: There is no significant difference in the performance of secondary school students taught physics using computer-assisted Jigsaw II cooperative setting and those taught using Individualized Computer Instruction (ICI).

To determine whether there was significant difference in the post-test mean scores of the computer-assisted Jigsaw II and the control group (ICI), data were analyzed using the analysis of covariance (ANCOVA). Table 1 contains the result of the analysis.

Table 1 shows the main effect of treatment group (computer-assisted Jigsaw II) on students performance produced an $F(1,77)=19.072, p=0.000)$ for the main effect (treatment) was significant, this indicates that the method of instruction produced a significant effect on the post-test achievement scores of students when covariate effect (pre-test) was controlled. The result indicated that the treatment, using Jigsaw II and ICl accounted for the difference in the post-test achievement scores of the students. Based on this result, Scheffe's test was used for post-hoc analysis. The results of this post-hoc analysis is shown in Table 2. 
Table 1. ANCOVA Post-test on Experimental (Jigsaw II) and Control (ICI) Groups

\begin{tabular}{llllll}
\hline $\begin{array}{l}\text { Source of } \\
\text { Variation }\end{array}$ & Sum of Square & df & Mean Square & $\mathrm{F}$ & $\mathrm{p}$ \\
\hline $\begin{array}{l}\text { Covariate } \\
\text { (Pre-test) }\end{array}$ & 587.599 & 1 & 587.599 & 12.003 & 0.001 \\
$\begin{array}{l}\text { Main Effect } \\
\text { (Treatment) }\end{array}$ & 933.609 & 1 & 933.609 & 19.072 & 0.000 \\
Model & 1561.303 & 2 & 780.652 & 15.947 & 0.000 \\
Residual & 3769.384 & 77 & 48.953 & & \\
Total & 343981.000 & 80 & & & \\
\hline
\end{tabular}

The performances of students in the two groups were further compared based on the mean gain scores between the pre-test and post test for each group and the results are shown in Table 2 and graphically illustrated in Figure 1.

Table 2. Mean Gain Scores of Students Taught Physics Using Jigsaw II and ICI

\begin{tabular}{lllc}
\hline Group & Pretest & Posttest & Mean Gain Score \\
\hline Jigsaw & 20.07 & 68.38 & 48.31 \\
$\mathrm{ICl}$ & 19.82 & 61.39 & 41.57 \\
\hline
\end{tabular}

From Table 2, it was observed that both groups had improved performance in post-test. For instance, Jigsaw II had highest mean gain scores of 58.58 while the (ICI) had mean gain scores of 41.31. This indicates that the two groups benefited from the treatment, with Jigsaw II having best performance.

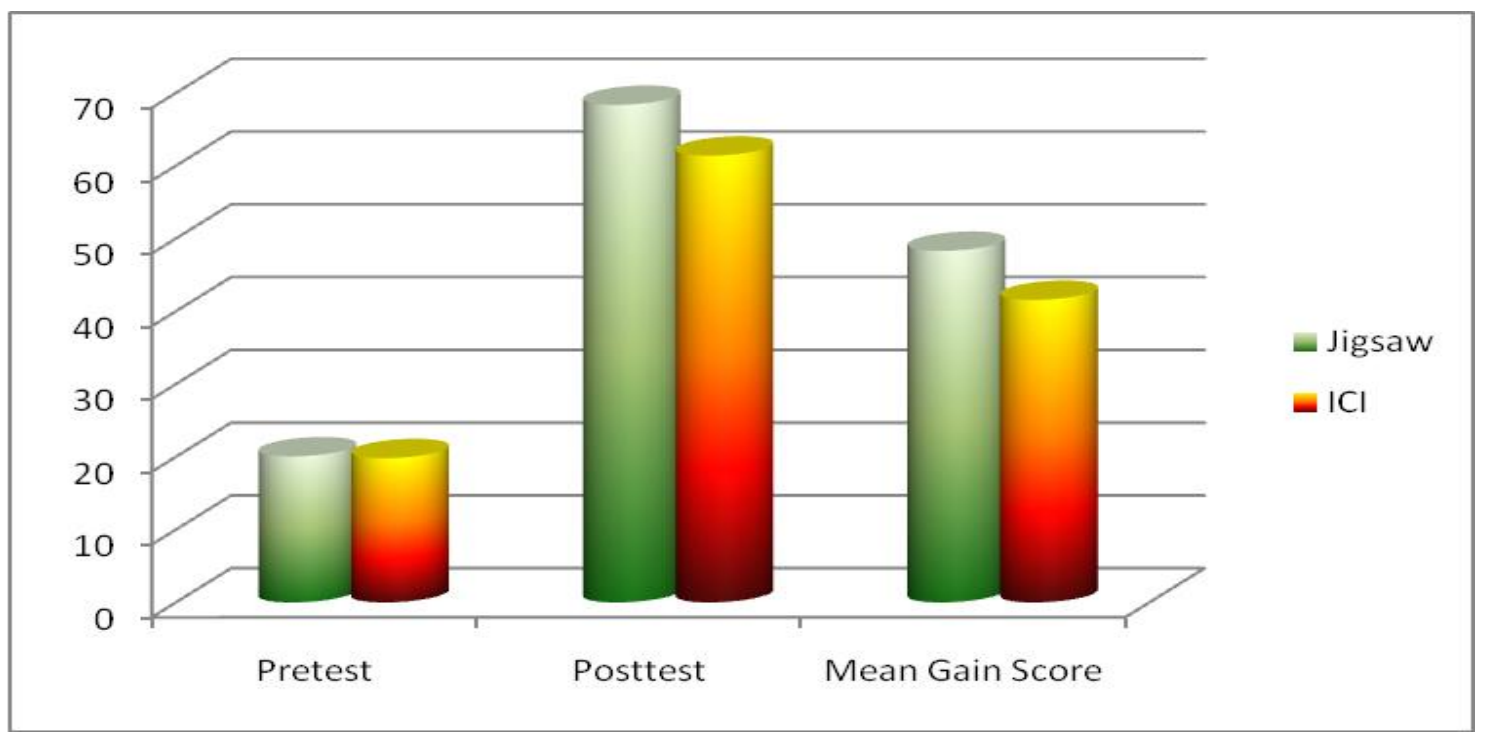

Figure 1. Graphical Illustration of Students' Performance in Jigsaw II and ICI 
Hypothesis Two: There is no significant difference in the performance of high, medium and low achievement level students taught physics using computer-assisted Jigsaw II cooperative setting.

To determine whether there were significant differences in the post-test mean scores of the computer-assisted Jigsaw II group, and the control group (ICI), data were analyzed using the analysis of covariance (ANCOVA). Table 3 contains the result of the analysis.

Table 3. Summary of ANCOVA Results on Achievement Levels

\begin{tabular}{llllll}
\hline $\begin{array}{l}\text { Source of } \\
\text { Variation }\end{array}$ & Sum of Square & df & $\begin{array}{l}\text { Mean } \\
\text { Square }\end{array}$ & $\mathrm{F}$ & $\mathrm{p}$ \\
\hline $\begin{array}{l}\text { Covariate } \\
\text { (Pretest) }\end{array}$ & 2.152 & 1 & 2.152 & 0.157 & 0.694 \\
$\begin{array}{l}\text { Main Effect } \\
\text { (Level) }\end{array}$ & 1131.069 & 2 & 565.534 & 41.226 & 0.000 \\
$\begin{array}{l}\text { Model } \\
\text { Residual }\end{array}$ & 1378.623 & 3 & 459.541 & 33.499 & 0.000 \\
Total & 521.282 & 38 & 13.718 & & \\
\hline
\end{tabular}

Table 3 indicates that an $F(1,38)=41.226, p=0.000$ was significant at 0.05 level. This shows the effect of the main effect (Computer-assisted Jigsaw II) when achievement levels were considered. The result indicates significant difference among the three achievement levels. The use of computer-assisted Jigsaw II accounted for the differences in their achievement scores. Since the existence of differences had been established, it remained to determine the direction of the difference. Scheffe's post-hoc analysis was adopted to compare the mean within the cells. The result of the Scheffe's analysis is shown in Table 4.

Table 4. Scheffe's Post-hoc Analyses of the Groups Mean Scores

\begin{tabular}{lllll}
\hline Groups & $\begin{array}{l}\text { Mean } \\
\text { Scores }\end{array}$ & $\begin{array}{l}\text { Group I } \\
\text { (High) }\end{array}$ & $\begin{array}{l}\text { Group II } \\
\text { (Medium) }\end{array}$ & Group III (Low) \\
\hline Group I (High) & 77.89 & & ${ }^{*} 0.000$ & ${ }^{*} 0.000$ \\
Group II (Medium) & 68.72 & ${ }^{*} 0.000$ & ${ }^{*} 0.000$ \\
Group III (Low) & 62.27 & ${ }^{*} 0.000$ & $* 0.000$ & \\
\hline
\end{tabular}

* The mean difference is significant at the 0.05 level.

The data in Table 4 indicates significant difference in the posttest mean scores of high achievers ( $X=77.89)$ and medium achievers $(\bar{X}=68.72)$ in favour of high achievers. It also indicates significant difference in the posttest scores between medium achievers $(\bar{X}=68.72)$ and low achievers $(\bar{X}=62.27)$ in favour of medium achievers. Significant differences was established in the posttest mean scores between high achievers $(\bar{X}=77.89)$ and low achievers $(\bar{X}=62.27)$ in favour of high achievers. 
The mean gain in achievement scores between pretest and posttest for the three achievement levels (high, medium and low) are shown in Table 5 and Figure 2 respectively.

Table 5 Mean Gain Scores of High, Medium and Low Students in Jigsaw II Group

\begin{tabular}{lllc}
\hline Group & Pretest & Posttest & Mean Gain Score \\
\hline High & 23.67 & 77.89 & 54.22 \\
Medium & 20.61 & 68.72 & 48.11 \\
Low & 17.27 & 62.27 & 45.00 \\
\hline
\end{tabular}

Table 5, indicates that high, medium and low achievement achievers (students) benefited from the treatment. However, there was difference in the mean gain scores of students of different achievement levels taught using computer-assisted Jigsaw II cooperative setting. The high achievers had 54.22 mean gain score; the medium achievers had a gain score of 48.11 which was higher than that of low achievers 45.00. The difference in mean gain scores between high and medium achievers was 6.11. The mean gain score between high and low achievers was 9.22. However, the difference in mean gain score between the medium and low achievers was 3.11. This is graphically illustrated in Figure 2.

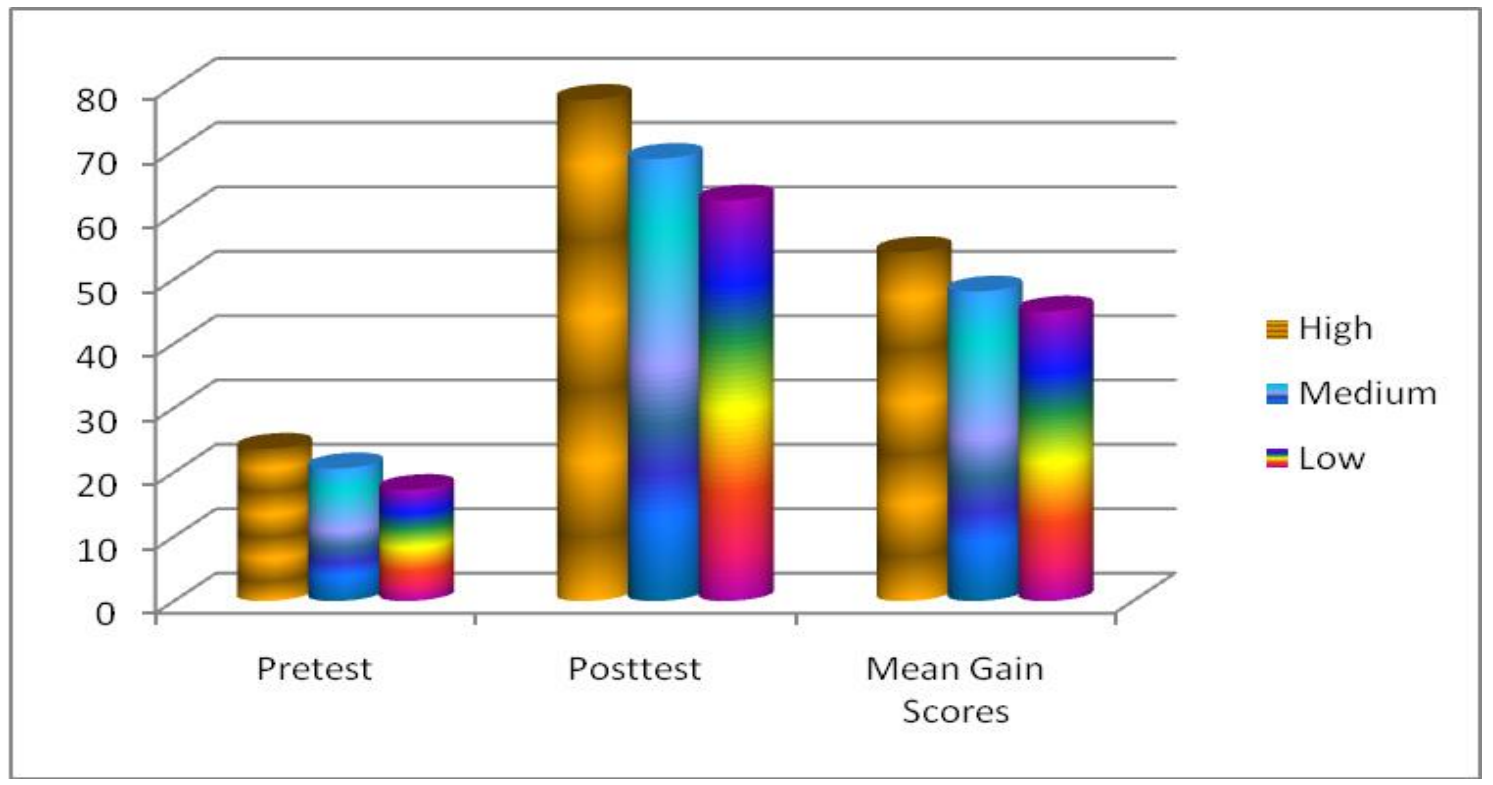

Figure 2. Graphical Illustration of High, Medium and Low Achievers in Jigsaw II Group

Hypothesis Three: There is no significant difference in the retention of secondary school students taught physics using computer-assisted Jigsaw II cooperative settings and those taught using Individualized Computer Instruction (ICI).

To determine whether there was significant difference in the posttest and retention test mean scores of students exposed to computer-assisted Jigsaw II cooperative setting, data were analyzed using the analysis of covariance (ANCOVA). The results on this hypothesis are as shown in Table 6. 
Table 6. ANCOVA Results of Retention Mean Scores of Students in Experimental Group

\begin{tabular}{llllll}
\hline $\begin{array}{l}\text { Source of } \\
\text { Variation }\end{array}$ & $\begin{array}{l}\text { Sum of } \\
\text { Square }\end{array}$ & $\mathrm{df}$ & $\begin{array}{l}\text { Mean } \\
\text { Square }\end{array}$ & $\mathrm{F}$ & $\mathrm{p}$ \\
\hline $\begin{array}{l}\text { Covariate } \\
\text { (Pretest) }\end{array}$ & 511.515 & 1 & 511.515 & 10.865 & 0.001 \\
$\begin{array}{l}\text { Main Effect } \\
\text { (Retention) }\end{array}$ & 820.859 & 1 & 820.859 & 17.436 & 0.000 \\
Model & 1367.453 & 1 & 683.726 & 14.524 & 0.000 \\
Residual & 3624.935 & 77 & 47.077 & & \\
Total & 292153.000 & 80 & & & \\
\hline
\end{tabular}

Table 6 revealed that an $F(1,77)=17.436, p=0.000$ for the main effect (retention) was significant; this indicates that the method of instruction produced a significant effect on the retention scores of students when covariate effect (posttest) was controlled. The results indicate that Jigsaw II and $\mathrm{ICl}$ accounted for the difference in the retention test achievement scores (retention) of the students. Based on these results, performances of students in the two groups were further compared using mean gain scores between the pre-test and retention test for each group and the results are shown in Table 7 and graphically illustrated in Figure 3.

Table 7. Mean Gain Scores of Students' Retention in Experimental (Jigsaw II) Group

\begin{tabular}{llcc}
\hline Group & Pretest & Retention test & Mean Gain Score \\
\hline Jigsaw II & 20.07 & 63.02 & 42.95 \\
$\mathrm{ICl}$ & 19.82 & 56.47 & 36.65 \\
\hline
\end{tabular}

Table 7 shows that both groups had improved performance in retention test. For instance, Jigsaw II had highest mean gain scores of 63.02 while the (ICI) had the least mean gain scores of 56.47. This indicates that the two groups benefited from the treatment, with Jigsaw II having better retention. Furthermore, the comparison in the mean scores between their pretest and posttest is shown in Figure 3.

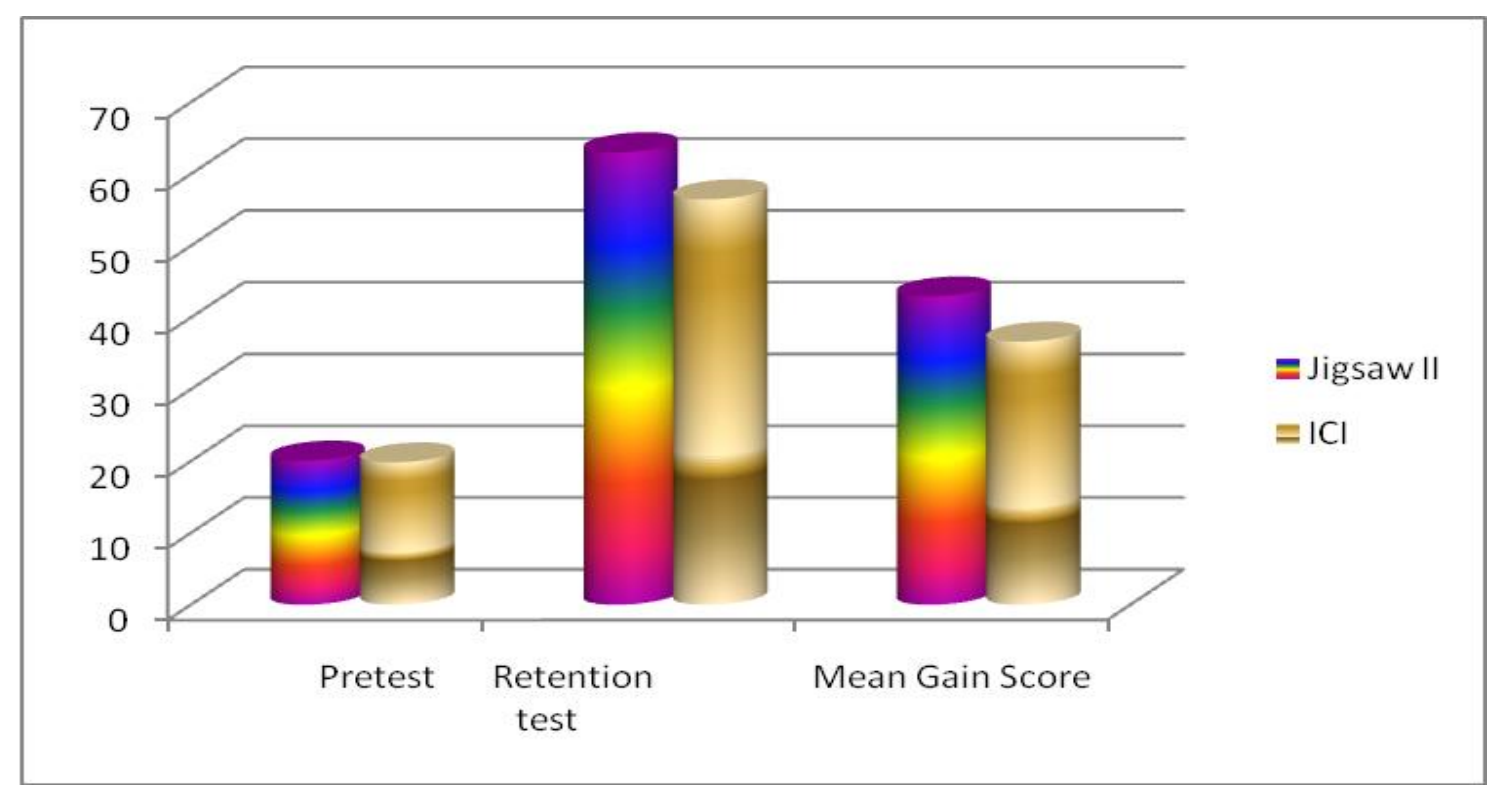

Figure 3. Graphical Illustration of Students' Retention in Experimental Group 


\section{Discussion}

The results of the analyses related to the hypothesis one indicated a significant difference in students' performance of in favour of those in the experimental group (Jigsaw II). Findings indicated significant difference between the performances of students exposed to Jigsaw II and $\mathrm{ICl}$. The findings as regards better performance of students in the Jigsaw II as compared to the $\mathrm{ICl}$ agree with earlier findings of Yusuf, Gambari and Olumorin (2012) and Keramati (2010) in physics and Yusuf and Afolabi (2010) in biology which reported that students taught using computer-assisted Jigsaw II CAI performed better than those taught using computer assisted instruction in individualised settings. Furthermore, this finding is supported by the findings of Lai and Wu (2006) in nursing education, (Hanze and Berger, 2007) and Berger and Hanze (2009) in physics, (Altiparmak \& Nakiboglu-Tezer, 2009) in chemistry, Mattinly, VanSickle and Ronald (2009) in geography, Moreno (2009), Doymus, (2008) and Jansoon, Somsook and Coll (2008) in biology, Zakaria, Solfitri, Daud \& Abidin (2013) in mathematics, Alshammari (2015), Azmin (2016) which reported that Jigsaw II is considerably more effective than individualistic instructional strategy and conventional classroom instruction respectively. However, the finding disagrees with the findings of Sengül and Katranci (2014), Shaaban (2006), Ross, Seaborn and Wilson (2002) and Thompson and Pledger (1998) who found no significant difference in the achievement of students taught using Jigsaw and those taught using conventional classroom and discussion methods respectively.

The superiority of computer-assisted Jigsaw II strategy stems from the fact that it was a task structured (task specialization) and incentive structured (group rewards for individual learning, group reward for group product, and individual rewards) cooperative strategy in such a way that if well implemented will produce a positive outcome. It was observed that Jigsaw II instructional strategies provide no room for free rider, in which some group members do all or most of the work while others go along for the ride (Slavin, 1995). Every member of the team must have learned the whole lesson in the home group, learn a portion in the Jigsaw group, then, takes turn to teach the portion to his teammates, complete individual and group tasks (Moreno, 2009).

The results of the analyses related to the hypothesis three indicated significant difference in the performance of high, medium and low students taught physics using computer-assisted Jigsaw II cooperative learning. The findings agree with the earlier findings of Ajaja and Eravwoke (2010), Gambari (2010) and Fuligni, Eccles and Barber (1995) which revealed that high and medium achievers were favoured than low achievers. However, it contradicts the findings of Yusuf (2004) which revealed that achievement levels had no influence on academic performance of the learners.

The results of the analyses related to the hypothesis three indicated significant difference in the retention of students taught physics using computer-assisted Jigsaw II cooperative learning and those taught using $\mathrm{ICl}$. The findings agree with the earlier findings of Tran and Vietnam (2014) and Kara (2008) which found significant difference between the experimental and control group in favor of experiment group in posttest and retention test. However, the findings contradict the findings of Moreno (2009) which revealed that there was no significant difference among learning approaches on retention.

The findings of this study emphasized on the teaching and learning of physics in secondary schools in Nigeria using computer assisted cooperative learning strategy. The findings revealed 
that computer assisted instruction is better in cooperative learning environment than in individualized setting. Furthermore, the findings provide sound empirical basis which indicate that performance of students in physics and other science subjects would be greatly improved if students are exposed to computer-assisted Jigsaw II cooperative learning strategy.

\section{Recommendations}

Based on the major findings of this study, the following recommendations are offered. Teachers should expose physics students to computer-assisted Jigsaw II cooperative instructional strategy so as to promote social interaction, active learning, discovery learning, motivation, learning by doing and learning by experience among students. In addition, Government, educational agencies (NERDC, NTI, NUC, etc.), NGOs, UNICEF, UNESCO, and other education stakeholders should organize workshops on the use of computer-assisted Jigsaw II cooperative learning strategies to enhance better performance of secondary school students. This research is of immense benefit to physics teachers and students in understanding the relevance and usage of technological tool such as computer to support cooperative learning strategy especially in the developing countries like Nigeria. This study has also contributed to knowledge in the area of Educational Technology.

\section{References}

Adegoke, B. A. (2011). Effect of multimedia instruction on senior secondary school students' achievement in physics. European Journal of Educational Studies, 3(3), 537-541.

Adetona, A. A. \& Rafiu, A. A. (2006). Application of M learning to distant learning programmes: A case study of open university system of Nigeria. Book of proceedings, $2^{\text {nd }}$ School of Science and Science Education Annual Conference, FUT Minna. Nigeria.

Ajaja, O. P. \& Eravwoke, O. U. (2010). Effects of cooperative learning strategy on junior secondary school students' achievement in integrated science. Electronic Journal of Science Education, 14(1). Retrieved from http://ejse.southwestern.edu

Alshammari, N. M. (2015). Effects of cooperative learning on academic performance of college students in Saudi Arabia. Unpublished Master Thesis, State University of New York at Fredonia, Fredonia, New York.

Altiparmak, M. \& Nakiboglu-Tezer, N. (2009). Hands on group work paper model for teaching DNA structure, central dogma and recombinant DNA. Online submission, US-China Education Review, 6(1), 19-23.

Azmin, N. H. (2016). Effect of the Jigsaw-based cooperative learning method on student performance in the general certificate of education advanced-level psychology: An exploratory Brunei case study. International Education Studies, 9(1), 91-96. doi:10.5539/ies.v9n1p91

Bajah, S. T. (2000). The state of science technology and mathematics education in Africa. UNESCO, (925) 3-4.

Cohen, E. (1994). Designing group work: Strategies for the heterogeneous classroom ( $\left.2^{\text {nd }} e d.\right)$. New York: Teachers College Press. 
Crosby, M. S. \& Owens, E. M. (1993). The disadvantages of tracking and ability grouping: A look at cooperative learning as an alternative. In National dropout prevention center Bulletin: Solutions and strategies, 5, 1-8.

Dishon, D., \& O'Leary, P. (1984). A guidebook for co-operative learning: A technique for creating more effective schools. Holmes Beach, FL: Learning Publications.

Essien, M. I. F. (2000). Tertiary institutions' administrators': Perception of students' levels of attainment of self-reliance through the implementation of 6-3-3-4 Educational System in Cross River State (Unpublished doctoral thesis). University of Calabar, Nigeria.

Federal Republic of Nigeria (2013). National policy on education. Lagos: Federal Government Press.

Fuligni, J. A., Eccles, J. S. \& Barber, B. L. (1995). The long-term effects of seventh-grade ability grouping in mathematics. The Journal of Early Adolescence, 15(1), 58-89. Retrieved on 14 December 2009 from http://jea.sagepub.com/cgi/content/abstract/15/1/58

Gambari, I. A. (2010). Effect of computer-assisted cooperative learning strategies on the performance of senior secondary students in physics, in Minna, Nigeria (Unpublished doctoral thesis). University of Ilorin, Ilorin, Nigeria.

Hanze, M. \& Berger, R. (2007). Cooperative learning, motivation effects, students' characteristics: An experimental study comparing cooperative learning and direct instruction in 12th grade physics classes. Learning and Instruction, 17(1), 29-41.

Johnson, D., Johnson, R., \& Johnson-Holubec, E. (1993). Co-operation in the classroom (6 ${ }^{\text {th }}$ ed.). Edina, MN: Interaction Book Company.

Johnson, R. T., Johnson, D. W., \& Stanne, M. B. (1996). Comparison of computer-assisted cooperative, competitive, and individualistic learning. American Educational Research Journal, 23(3), 382-392.

Kara, I. (2008). The effect on retention of computer assisted instruction in science education. Journal of Instructional Psychology, 35(4), 357-364.

Keramati, M. (2010). Effect of cooperative learning on academic achievement of physics course. Journal of Computers in Mathematics and Science Teaching, 29(2), 155 -173.

Mathew, F. (2002). The effect of gender and parental influence on students' achievement in the teaching and learning of science. Keynote address delivered on the speech and prize giving day: Government day secondary school, Idofin.

Mattingly, R. M. \& VanSickle, R. L. (2009). Cooperative learning and achievement in social studies: Jigsaw II. Retrieved on 24 December 2009 from http://www.eric.ed.gov/ ERICWebPortal/Home.portal=ED348267.

Michael, P. (2006). The importance of physics: Breakthroughs drive economy, quality of life, world leaders, public increasingly take scientific advances for granted. Retrieved on 29 April 2007 from http://www.physics2005.org.

Moreno, R. (2009). Constructing knowledge with an agent-based instructional program: A comparison of cooperative and individual meaning making. Learning and Instruction, 19(5), $433-444$.

Okebukola, P. (1999). An assessment of laboratory facilities in Nigeria schools and its effect on students' achievement. Journal of Science Teacher's Association of Nigeria (STAN) Special edition, 21-43. 
Olorukooba, S. B. (2007). Science, technology and mathematics (STM) education is for all students: Promoting effective teaching of STM subjects in our schools through teacher preparation. Proceedings of the $50^{\text {th }}$ Anniversary Conference of Science Teachers Association of Nigeria. Pp3-6

Omosewo, E. O. (2000). Effect of family type on secondary school students' performance in physics in Ilorin metropolis. The Nigeria Journal of Guidance and counselling, 7(1), 184195.

Osemwinyen, A. C. (2009). Effects of e-learning on retention and achievement in secondary school mathematics in Abuja, Nigeria (Unpublished doctoral thesis). University of Nigeria, Nsukka.

Shaaban, K. (2006). An initial study of the effects of cooperative learning on reading comprehension, vocabulary acquisition, and motivation to read. Reading Psychology, 27(5), 377-403.

Ross, M. C., Seabborn, A. W., \& Wilson, E. K. (2002). Is cooperative learning a valuable instructional method for teaching social studies to urban African American students? Retrieved on 5 February 2008 from http://www.eric.ed.gov/ERICWebPortal/Home. portal=(ED480458).

Schmidt, K. (2002). Computer-assisted cooperative work and learning. Retrieved on 5 May 2007 from http://www.uoc.edu/web/esp/art/uoc/schmidt0202/schmidt0202.html 30/ 04/2011.

Sengul, S. \& Katranci, Y. (2014). Effects of jigsaw technique on mathematics self-efficacy perceptions of seventh grade primary school students. Procedia of5th World Conference on Educational Sciences - WCES 2013. Social and Behavioral Sciences, 116, 333-338. doi: 10.1016/j.sbspro.2014.01.217

Shawl, A. (2003). An adoption of problem based teaching and problem-based learning to improve the teaching of radioactivity. Chinese Journal of Elementary Science, 3 (1), 1418.

Slavin, R. E. (1995). Research on cooperative learning and achievement: What we know, what we need to know. Retrieved on 5 May 2007 from http://www.scov.csos.jhu.edu/sfa/ cooplear.html

Stephen, B. M. (2003). The design of construction of a tickertape vibrator for teaching physics in secondary schools (Unpublished M. Tech. Project). Department of Science Education. Federal University of Technology, Minna.

Tran, V. D. \& Vietnam, A. G. (2014). The effects of cooperative learning on the academic achievement and knowledge retention. International Journal of Higher Education, 3(2), 131-140. Available at http://dx.doi.org/10.5430/ijhe.v3n2p131-140

West African Examination Council, (WAEC, 2004, 2005, 2006, 2007 \& 2008). May/June. Chief Examiner's Report. Lagos.

Yager, S., Johnson, D. W. \& Johnson, R. T. (1985). Oral discussion, group-to-individual transfer, and achievement in cooperative learning groups. Journal of Educational Psychology, 77(1), 60-66.

Yar'adua, U. M. (2008). The presidential speech. Retrieved on 9 January 2009 from http://www.centralbank.org. 
Yusuf, A. (2004). Effects of cooperative and competitive instructional strategies on junior secondary school students' performance in social studies, in llorin, Nigeria (Unpublished doctoral thesis). Curriculum Studies and Educational Technology, University of Ilorin, Nigeria

Yusuf, M. O. \& Afolabi, A. O. (2010). Effects of computer assisted instruction (CAI) on secondary school students' performance in biology. The Turkish Online Journal of Educational Technology, 9(1). Retrieved on 15 January 2010 from http://www.tojet.edu. com

Yusuf, M. O., Gambari, A.I. \& Olumorin, C. O. (2012). Effectiveness of computer-supported cooperative learning strategies in learning physics. International Journal of Social Sciences \& Education, 2(2), 94-109.

Zakaria, E., Solfitri, T., Daud, Y. \& Abidin, Z. Z. (2013). Effect of cooperative learning on secondary school students' mathematics achievement. Creative Education, 4(2), 98-100. Retrieved on 13 March 2015 from http://www.scirp.org/journal/ce.

Correspondence: Isiaka Amosa Gambari, Senior Lecturer, Department of Science Education, Federal University of Technology, Minna, Nigeria 